\title{
Cell Cycle Regulation and Induction of Apoptosis by $\beta$-carotene in U937 and HL-60 Leukemia Cells
}

\author{
Upadhyaya K. R. ${ }^{1}$, Radha K. S. ${ }^{2}$ and Madhyastha H. K. ${ }^{2, *}$ \\ ${ }^{1} \mathrm{R} \& \mathrm{D}$ division, Bayier Extracts Ltd, Bangalore, India \\ ${ }^{2}$ Department of Applied Physiology, Faculty of Medicine, University of Miyazaki, Miyazaki, Japan
}

Received 15 March 2007, Accepted 30 July 2007

\begin{abstract}
In this communication, we report the efficacy of $\beta$-carotene towards differentiation and apoptosis of leukemia cells. Dose $(20 \mu \mathrm{M})$ and time dependence $(12 \mathrm{~h})$ tests of $\beta$-carotene showed a higher magnitude of decrease (significance $p<0.05$ ) in cell numbers and cell viability in HL-60 cells than U937 cells but not normal cell like Peripheral blood mononuclear cell (PBMC). Microscopical observation of $\beta$-carotene treated cells showed a distinct pattern of morphological abnormalities with inclusion of apoptotic bodies in both leukemia cell lines. When cells were treated with $20 \mu \mathrm{M}$ of $\beta$-carotene, total genomic DNA showed a fragmentation pattern and this pattern was clear in HL-60 than $\mathrm{U} 937$ cells. Both the cell lines, on treatment with $\beta$ carotene, showed a clear shift in $\mathbf{G}_{\mathbf{1}}$ phase of the cell cycle. In addition the study also revealed anti-oxidant properties of $\beta$-carotene since there was reduction in relative fluorescent when treated than the control at lower concentration. Collectively this study shows the dual phenomenon of apoptosis and differentiation of leukemia cells on treatment with $\beta$-carotene.
\end{abstract}

Keywords: $\beta$-carotene, DNA fragmentation, Cell cycle, Intracellular oxygen tension leukemia cells

\section{Introduction}

There is a expanding source of information on the potential application of synthetic non-steroidal, anti-inflammatory drugs (NSAIDS) in cancer prevention but the rate of prevention is

\footnotetext{
Abbreviations: HL-60, Human leukemia cells; PBMC, peripheral blood mononuclear cells; DMSO, di methyl sulphoxide; DCFA-DA, dichloro dihydrofluorescein diacetate.
}

\footnotetext{
*To whom correspondence should be addressed. Tel: 81-985-85-1785; Fax: 81-985-85-7932

Email: hkumar@med.miyazaki-u.ac.jp
}

limited to only $40 \%$ since the drugs efficacy is associated with side effects to human body (Schreinemachers and Everson, 1994). Alternate search for different modes of chemoprevention which are more effective in preventing and reducing the risk of cancer growth is consistently gaining immense focus. Nutraceuticals from microorganisms, algae and plant have attained immense importance in cancer prevention (McCarty and Block, 2006). A large scale cohort study showed that intake of major carotenoids prevented ovarian cancer (Genkinger et al., 2006; Koushik et al., 2006). Nutritional factors like carotenoids can also influence the cellular differentiation, apoptosis programme and cellular anti-proliferation potential with different molecules as target points (Neuhouser et al., 2003; Aggarwal and Shishodia, 2006). Recent studies showed that antioxidants, vitamins and related nutrients are able to influence the carcinogenic process by governing the cellular process in the pathogenesis of cancer (Altucci et al., 2001; Paolini et al., 2003; Maillard et al., 2006). Among total carotenoids there is experimental evidence that $\beta$-carotene can modulate molecular pathways involved in the cell cycle progression and enhance apoptosis in un differentiated leukemia cells (Palozza et al., 2002; Aggarwal and Shishodia, 2006). Dietary role of $\beta$-carotene as antioxidative agent is discussed very well in cancer biology and oxidative stress (Jarrett et al., 2006). All trans retinoic acid (ATRA) is one of the major physiologic stimulator able to regulate proliferation and differentiation of haematopoietic cells receptor (Collins, 2002) and the activity depends on the structure of the carotenes (Konishi, et al., 2006). Apoptosis plays a crucial role in normal development, homeostasis and in the defense response against pathogens. This kind of cell death is thought to be an important response to most chemotherapeutic agents in leukemia cells. However the biochemical mechanism of $\beta$ carotenes action in the well differentiated leukemia cells remains unclear. This study elucidates some aspects of the $\beta$ carotene action in acute and differentiated human leukemia cells like HL-60 and U937 and also in normal cells and its possible mechanism of action causing cell death. 


\section{Materials and Methods}

Chemicals. Commercially available $\beta$-carotene, agarose, DMSO, DCFA-DA and propidium iodide were purchased from Sigma (Sigma-Aldrich). All other chemicals, reagents and solvents were purchased from SD fine chemicals and Qualigen and Wako pure chemicals. Phosphate buffered saline (PBS), RPM1 medium, fetal bovine serum (FBS), penicillin and streptomycin were purchased from GIBCO (GIBCO Bioscience). Culture vessels were purchased from Nunc, Denmark.

Cell culture and treatment. Human chronic monocytic leukemia U937 and myeloid leukemia, HL-60 (promyelocytic cells) obtained from American Type Culture Collection and normal PBMC cells were grown in RPMI 1640 medium supplemented with $10 \%$ heat inactivated fetal bovine serum (FBS), $100 \mathrm{IU}$ penicillin, $100 \mu \mathrm{g} / \mathrm{ml}$ streptomycin and $2 \mathrm{mM}$ L-glutamine. Human peripheral mononuclear cells (PBMC) were isolated from heparin-anticoagulated blood of healthy persons by centrifugation with Ficoll-Paque Plus (Amersham Biosciences). Cell stock culture was maintained in liquid nitrogen and experiments were conducted with periodic changes of culture. Experimental sets were maintained in a humidified atmosphere with $5 \% \mathrm{CO}_{2}$ and $37^{\circ} \mathrm{C}$. The initial culture density for experiments was $1 \times 10^{5} \mathrm{cell} / \mathrm{ml}$. $\beta$-carotene was dissolved in di-methyl sulphoxide (DMSO) and concentration was adjusted according to the dose applied. The final concentrations of di-methyl sulfoxide (DMSO) in the culture medium was $<0.03 \%$. The concentrations used were 0 , $5,10,20,50$ and $100 \mu \mathrm{M} .0 \mu \mathrm{M} \beta$-carotene means addition of DMSO alone. Initially, HL-60 and U937 cells were co-incubated with various concentrations of $\beta$-carotene for $24 \mathrm{~h}$ and the dose dependency test was studied. After selection of specified dose, time duration study was conducted. Cell viability test was carried out using the Beckman-Coulter automatic cell counter (VI-cell analyzer, Beckman Coulter, Inc).

MTT reduction assay. Cell proliferation assay was determined using MTT assay (Mosmann, 1983). U937, HL-60 and PBMC cells $\left(1 \times 10^{5} \mathrm{cells} / \mathrm{ml}\right)$ were incubated in 96 well plates with difference doses of $\beta$-carotene $(0,5,10,20,50$ and $100 \mu \mathrm{M})$ for $12 \mathrm{~h}$. Ten $\mu \mathrm{l}$ of MTT $(10 \mathrm{mg} / \mathrm{ml})$ was added to each well and incubated further at $37^{\circ} \mathrm{C}$ for $4 \mathrm{~h}$. After incubation, MTT-formazan precipitate was dissolved in $100 \mu \mathrm{l}$ of DMSO and absorbance was recorded at $570 \mathrm{~nm}$ in automatic plate reader (BioRAD instrument). Three independent experiments were conducted to quantify the data.

2.4 Cytotoxicity assay. Cytotoxicity parameters of $\beta$-carotene on U937 and HL-60 cells were carried out using LDH assay kits. (CytoTox $96^{\mathrm{R}}$ Non-radioactive cytotoxicity assay, Promega, Madison, USA). Red formazon - a product of conversion of tetrazolium salt (INT) was quantified using multi plate reader (BioRAD instrument). Data are presented as percentage of cytotoxicity of treated VS untreated cells.

DNA ladder assay. DNA ladder assay was carried out as per standard method (Herrmann et al., 1994). This method prevents the contamination of entire genomic DNA with fragmented DNA. Briefly, after treatment with $\beta$-carotene, cells were harvested, washed twice with cold PBS and lysed for $30 \mathrm{~min}$ at $4^{\circ} \mathrm{C}$ in lysis buffer (50 mM Tris-HCl (pH 7.5), 1 mM EDTA, 0.2\% Triton X100) using zirconium beads and automatic cell lyser (MS-100 R, Tomy, Medico Ltd.). After centrifugation at $15,000 \times g$ for $20 \mathrm{~min}$, the supernatant was treated with protease inhibitor cocktail and $0.5 \%$ SDS for $1 \mathrm{~h}$ at $37^{\circ} \mathrm{C}$. DNA was extracted twice with phenol and precipitated with $150 \mathrm{mM} \mathrm{NaCl}$ and two volumes of ethanol at $-20^{\circ} \mathrm{C}$. DNA precipitate was washed twice with $70 \%$ ethanol, dissolved in TE buffer and treated for $1 \mathrm{~h}$ with Rnase at $37^{\circ} \mathrm{C}$. Finally, DNA precipitates were stained with propidium iodide, electrophoresed on $2 \%$ agarose gel and visualized in an automatic gel documentation system (BIO-RAD systems).

Confocal microscopy. $\beta$-carotene-treated as well as non-treated U937 and HL-60 cells were fixed and stained with wright-giemsa stain on cover-glass slides and observed under light microscope with $400 \times$ magnification (Nikon Optihot model \# 88, Osaka, Japan) for apoptotic body accumulation. Photos were taken with a digital camera (Canon).

Cell cycle analysis by Flow cytometer. Cell cycle analysis was done as described previously (Noguchi and Browne, 1978; Jing et al., 1994). Briefly, treated and untreated cells were harvested by centrifugation and washed once with cold PBS. The cells were fixed with ice-cold $70 \%$ ethanol at a cell density of $1 \times 10^{6}$ and then treated with $1 \mathrm{mg} / \mathrm{ml} \mathrm{RNase}$ for $30 \mathrm{~min}$ at $37^{\circ} \mathrm{C}$. Propidium iodide was added to the cell solution at a final concentration of $50 \mu \mathrm{g} / \mathrm{ml}$ The rate of cell cycle were analysed by quantification of DNA content in a Coulter ${ }^{\circledR}$ Epics $^{\circledR}$ XL $^{\text {TM }}$ Flow Cytometer (Beckman Coulter, Inc).

Cellular redox potential assay. Cells were treated with different concentrations of $\beta$-carotene and incubated for prescribed period. After incubation period, cells were harvested and washed with cold PBS. Washed cells were further incubated with 2',7-dichlorofluoresceindi-acetate (DCFH-DA) at $37^{\circ} \mathrm{C}$ for $1 \mathrm{~h}$ in dark. Intracellular ROS generation was investigated by quantifying $\mathrm{H}_{2} \mathrm{O}_{2}$ by Coulter ${ }^{\circledR}$ Epics $^{\circledR} \mathrm{XL}^{\mathrm{TM}}$ Flow Cytometer (Beckman Coulter, Inc).

Statistical analysis. Each experiment was carried out in three independent sets. Mean values and standard deviation were calculated. Student ' $t$ ' test for each set of experiments was calculated in all groups. Statistically significant values was set at the level of $p<0.05$.

\section{Results}

Effect of $\beta$-carotene on cells. First, we analysed the uptake of the $\beta$-carotene in the U937, HL-60 and normal PBMC cells after lysing treated cells and analyzing cellular $\beta$-carotene content by spectrophotometer. Results showed that accumulated $\beta$-carotene was in the range of 60-250 pmol level (results not shown). This cellular uptake study analysis confirmed the optimal uptake by the cells and formed the basis for further treatment. A dose-dependent decrease of cell numbers in both cell lines was noticed during $12 \mathrm{~h}$ treatment (Fig. 1), with maximum and significant $(p<0.05)$ decrease at $20 \mu \mathrm{M}$ concentration. Among the tested cell lines, a differential 


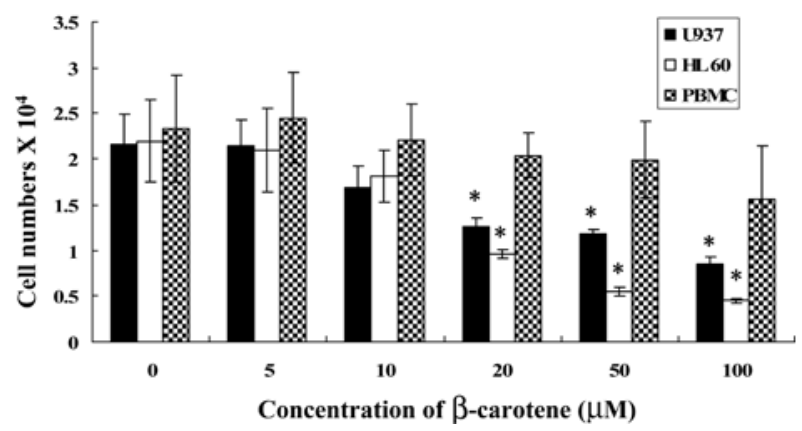

Fig. 1. Cell proliferation assay. U937, HL-60 cells and normal cells PBMC)were cultured in RPM 1648 medium with various concentrations of $\beta$-carotene for $24 \mathrm{~h}$. Cell numbers were counted by trypan dye exclusion method. Values are expressed as mean \pm S.D. of three independent experiments. Significant levels were set as $p<0.05 .0 \mu \mathrm{M}$ indicates DMSO alone. $P$-values $\leq 0.05$ with * mark were considered significant.

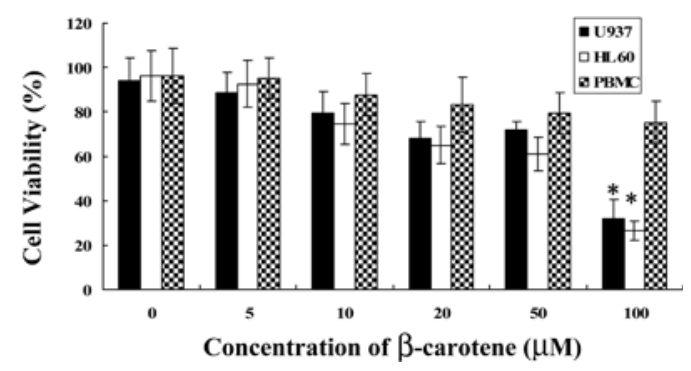

Fig. 2. Cell viability test. Dose-dependent growth inhibition and cytotoxic effect of various concentrations of $\beta$-carotene were tested on U937, HL-60 cells and normal cells (PBMC). The cells were treated for $24 \mathrm{~h}$. Total viable cells were counted with automatic cell counting unit. Data presented are the means of three independent experiments. $0 \mu \mathrm{M}$ indicates DMSO alone. $P$-values $\leq 0.05$ with * mark were considered significant.

behavior was observed in the cytotoxic effect of the $\beta$ carotene, where a higher susceptibility was found in cell viability in HL-60 cells up to $50 \mu \mathrm{M}$ in trypan blue dye exclusion study (Fig. 2). The decrease in cell numbers and cell viability show that $\beta$-carotene did kill the cells at concentrations higher than $20 \mu \mathrm{M}$. Based on these results, the molecular mechanisms involved in the generation of the antitumor action of these derivatives are now being explored

Cell proliferation/cytotoxicity study. Once we confirmed the degree of $\beta$-carotene effect to U937, HL-60 and normal PBMC cells, we confined our goal of cytotoxicity study towards leukemia cells lines. The cytotoxic property of $\beta$ carotene was evaluated by the aid of LDH release assay and MTT dye exclusion assay. The limit of the activity was defined as $\mathrm{IC}_{50}$ value. Fig. 3 explains the $\mathrm{LDH}$ release during the treatment with different concentrations of $\beta$-carotene in U937 and HL-60 cells. LDH release to the medium during the drug treatment is the hallmark of cytotoxicity of the compound

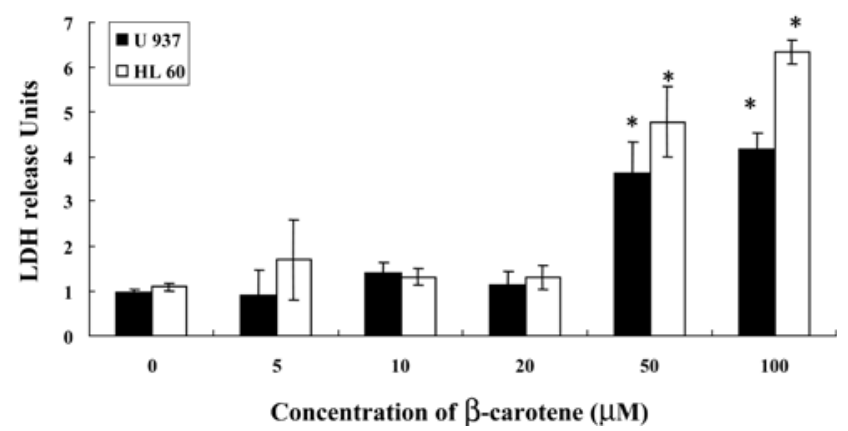

Fig. 3. LDH release assay. U937 and HL-60 cells were seeded in 6 well plates with various concentrations of $\beta$-carotene. Percentage of LDH was measured by CytoTox Non-radioactive cytotoxicity assay Kit (Promega Corp. Madison, WI, USA). Significant levels were set as $p<0.05 .0 \mu \mathrm{M}$ indicates DMSO alone. $P$-values $\leq 0.05$ with * mark were considered significant.

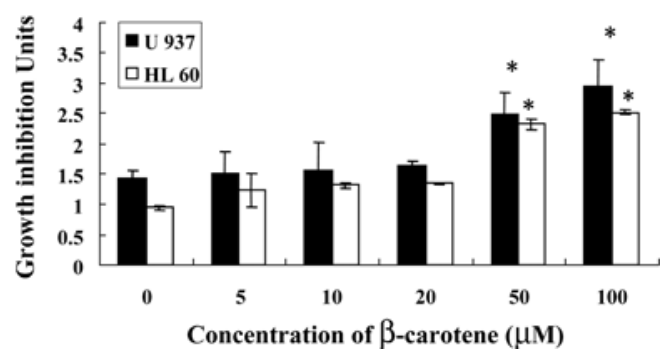

Fig. 4. MTT dye reduction assay. U937 and HL-60 cells were treated with various concentrations of $\beta$-carotene for $24 \mathrm{~h}$ and MTT dye reduction assay was carried out as per manufacturer's instructions (Promega Corp. Madison, WI, USA). Values are expressed as three independent observations. Significant levels were set as $p<0.05 .0 \mu \mathrm{M}$ indicates DMSO alone. $P$-values $\leq 0.05$ with $*$ mark were considered significant.

because of membrane lysis and oxidation reaction of lactate to pyruvate and subsequent reaction of pyruvate with INT tetrazolium to form formazan. A significant accumulation of formazan was noticed in doses higher than $20 \mu \mathrm{M}$, clearly showing the degree of toxicity of $\beta$-carotene in both cell types studied. This observation was further confirmed by MTT dye reduction assay and results are depicted in Fig.4. There was a stronger and significant $(p<0.01)$ growth inhibition effect of $\beta$-carotene at doses higher than $20 \mu \mathrm{M}$. However, there was no strong difference in reduction between $50 \mu \mathrm{M}$ and $100 \mu \mathrm{M}$ probably due to apoptosis and/or necrosis in both cell lines. In both cases more than $80 \%$ of dead cells were observed (Figs. 1 and 2).

Cell morphology and DNA fragmentation study. In order to identify the cause for cell number decrease, we studied the cell morphology to test whether cell death was a result of apoptosis during the $\beta$-carotene treatment. Fig. 5 shows a characteristic accumulation of apoptotic bodies in both cells after treatment as denoted by the arrow mark at a concentration 

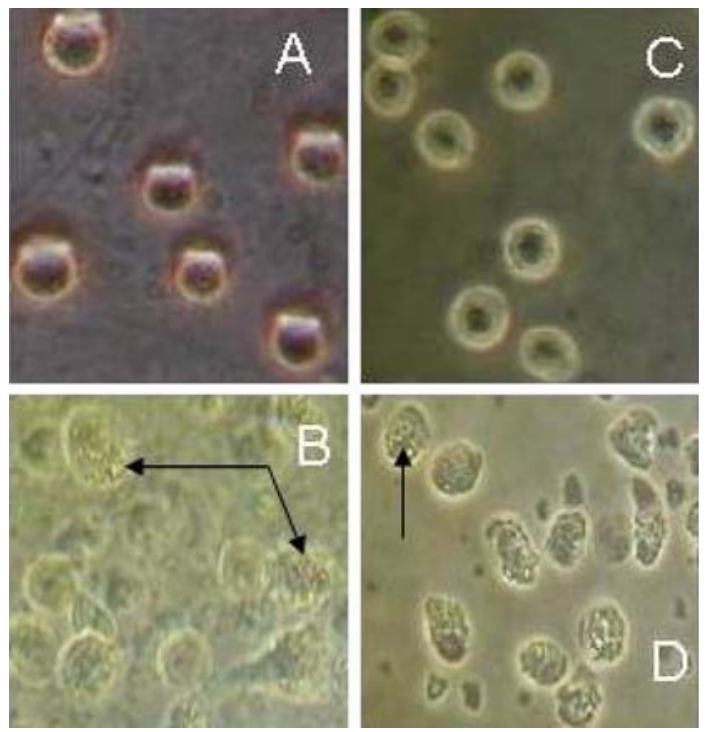

Fig. 5. Morphological appearance of apoptotic cells by confocal microscopy. U937 and HL-60 cells were treated with $20 \mu \mathrm{M} \beta$ carotene for $24 \mathrm{~h}$. Cells were harvested, fixed and stained with Wright-Giemsa stain. Obervations were made under phase contrast microscope. Arrow indicates the apoptotic cells. A. U937 control cells;. B. U937 $\beta$-carotene treated cells; C. HL-60 control cells; D. HL-60 $\beta$-carotene treated cells.
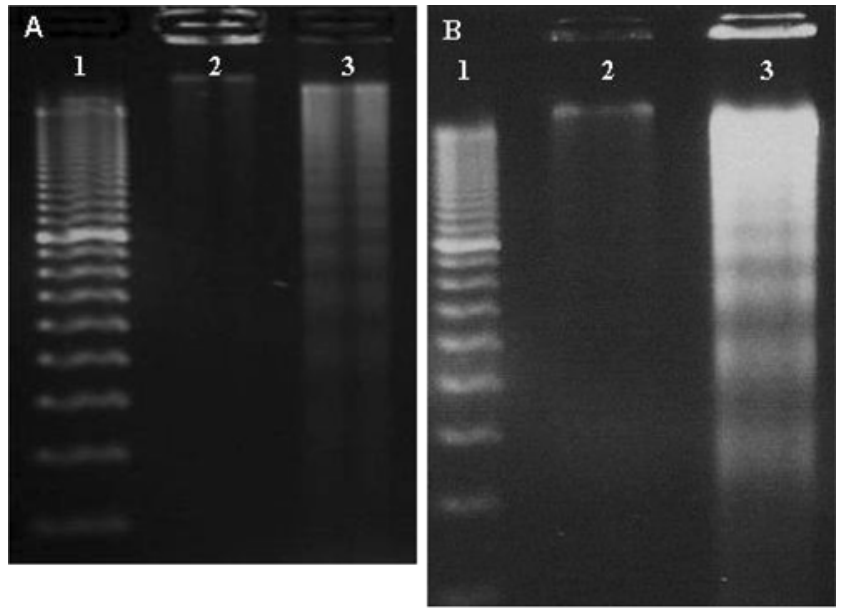

Fig. 6. DNA ladder assay. Agarose gel electrophoresis of DNA from U937 and HL-60 cells treated with $20 \mu \mathrm{M} \beta$-carotene. The gels were photographed under UV illumination. A U937 cells; B HL-60 cells; Lane 1. Molecular marker; Lane 2. Control cell; Lane 3 Treated cells. $0 \mu \mathrm{M}$ indicates DMSO alone.

of IC-50. The number of apoptotic bodies also increased with increasing concentration of $\beta$-carotene (results not shown). The morphological changes of the cells were further ascertained by a strong biochemical confirmatory assay-DNA fragmentation study and results are depicted in Fig. 6. Inter nucleosomal cleavage of cellular DNA by endonuclease to size less than $180 \mathrm{bp}$ could be detected by agarose gel electrophoresis and
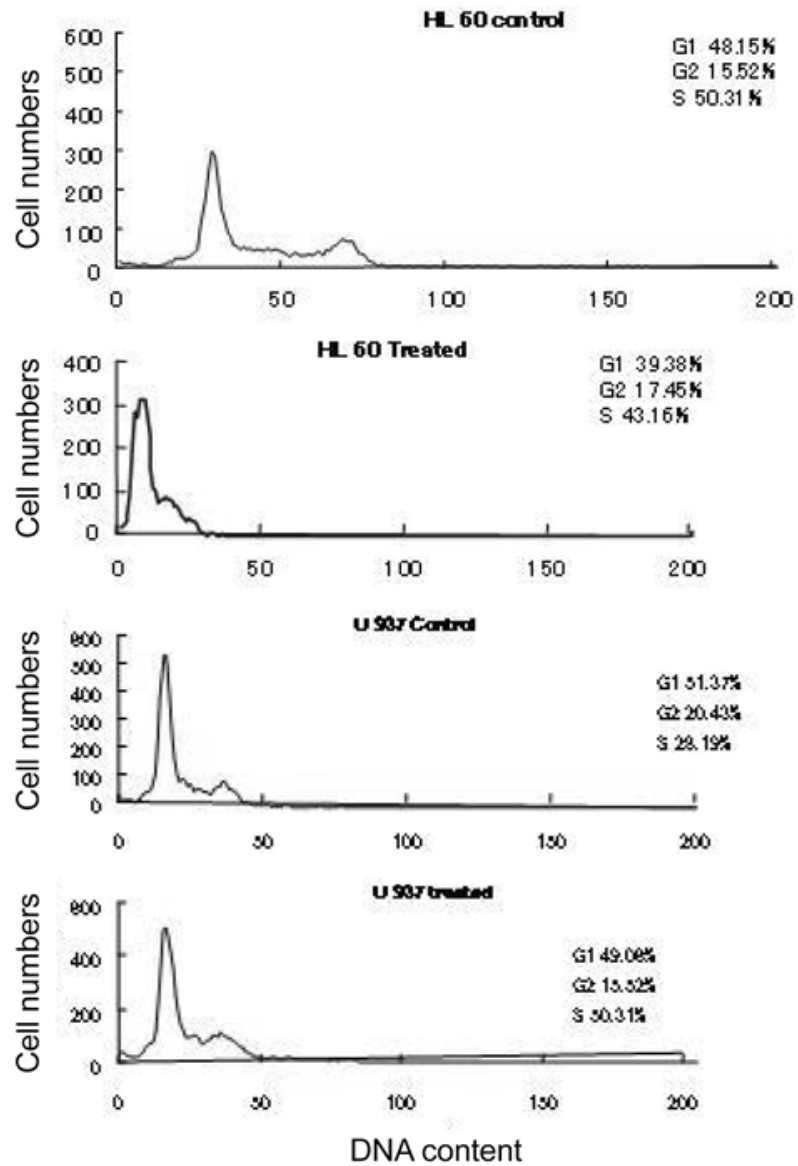

250

Fig. 7. Flow cytometer analysis of cell cycle. After $\beta$-carotene treatment, cells were harvested, washed with PBS and DNA content was analyzed by flow cytometer. The results are expressed as DNA content vs. cell number. $0 \mu \mathrm{M}$ indicates DMSO alone.

PI Staining. As illustrated in Figs. 6a and 6b, the rate of fragmentation was clear in HL-60 cells than U937, reason being unknown at present. Control cells did not show any DNA fragmentation (Figs. 6 a \& b lane 1). This type of nucleosomal cleavage reflects the activity of endonuclease which might have been induced by $\beta$-carotene.

Cell cycle study by flow cytometer. Having confirmed the nature of cell death, we further directed our study towards the cell cycle pattern during the cell death. The degree of apoptosis in $\beta$-carotene treated cells was further evaluated by DNA content through flow cytometric analysis. Fig. 7 illustrates the different phases of cell cycle in treated and control cells. The control group showed a prominent $\mathrm{G}_{1}$ phase of $49 \%$ and $51 \%$ in HL-60 and U937 cells respectively; whereas, in treated cells a significant reduction of $\mathrm{G}_{1}$ phase to $39.4 \%$ in HL-60 and a small reduction of $\mathrm{G}_{1}$ in U837 cells was observed. This result suggests a possibility that $\beta$-carotene induces apoptosis by arresting $\mathrm{G}_{1}$ phase. In addition to these changes, the presence of distinct sub $\mathrm{G}_{1}$ peak (sub diploid 


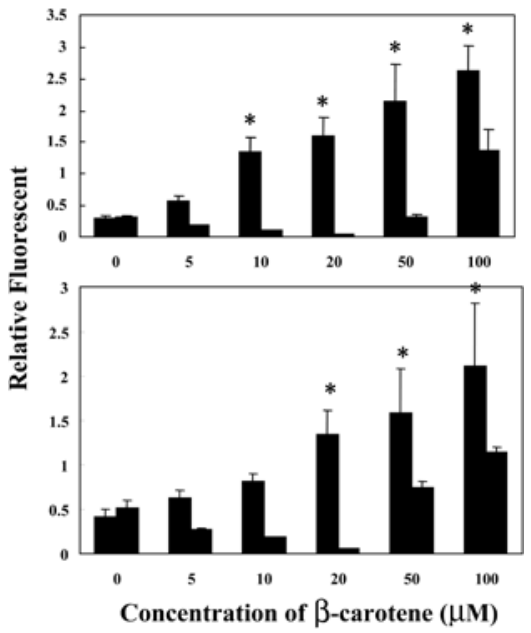

Fig. 8. Quantification of intracellular ROS generation Cells $\left(10^{4}\right.$ cells $/ \mathrm{ml}$ ) treated with varying concentrations of $\beta$-carotene for $24 \mathrm{~h}$ were harvested to evaluate cellular peroxide content by DCFH-DA labeling. Before addition of fluorescent probe, culture media was removed to eliminate the amount of $\beta$-carotene and/or antioxidants that were not cell associated. Untreated cells. treated cells. $0 \mu \mathrm{M}$ indicates DMSO alone.

content), a characteristic of apoptoic cells was also noticed (result not shown).

Intra cellular ROS generation assay by flow cytometer. Oxidative stress is a central action for the anticancer effects, since oxidative stress is coupled with many signals inducing apoptosis (Phalen 2006). The radical scavenging activity of the tested compounds was influenced by the number and location of hydroxyl groups, glycosylation, and other substitutions. To investigate the possible mechanism by which $\beta$-carotene could interfere with intra cellular ROS generation in leukemia cells due to oxidative stress, we evaluated the cellular ROS content by flow cytometer with the aid of DCFH-DA labeling of. Fig. 8 depicts the pattern of flourescence spectra in two experimental groups of treated and non treated groups. $\beta$-carotene addition deeply modified intracellular ROS levels. At lower concentrations, $\beta$-carotene acted as antioxidant but at higher level it showed pro-oxidant nature. The maximum effect of antioxidant phenomenon was noticed up to $20 \mu \mathrm{M}$ in both cells. On the other hand fluorescent in untreated gropus increased gradually. This clearly indicates pro-oxidants and antioxidant nature of $\beta$ carotene.

\section{Discussion}

The present study demonstrated that $\beta$-carotene can act as both apoptotic inducer as well as antioxidant compound in human leukemia cell lines. $\beta$-carotene is one of the major water insoluble but solvent soluble natural colorants widely present in majority of fruits and vegetables and used as a source of chemopreventive agents. First, we have studied and demonstrated that $\beta$-carotene demonstrates antiproliferative and apoptotis inducing properties on human leukemia cell lines. Cytotoxicity can be defined as the cell killing property of a chemical compound independent from the mechanism of death. Our results show that the carotene induced a dose dependent inhibition of cell growth in both cell lines studied but not normal cell (PBMC). The degree of inhibition was severe in HL-60 than the U937 cells, implying that activity is cell dependent. HL-60, a leukemic cell line has been extensively studied as an able cell line because of its nature to differentiate into morphologically mature myeloid cell, a phenomenon similar to neutrophils after certain drug treatment (Covacci et al., 1998). This inhibition phenomenon ultimately leads to the inhibition of cell proliferation followed by cell death via apoptosis (Palozza et al., 2002). When considering the chemotherapy side effects, it is very important to verify whether the compound shows a harmful effect against normal dividing cells such as proliferating mononuclear cells such as PBMC. The present investigation shows a stronger cytotoxic effect of $\beta$-carotene as confirmed by LDH release (Fig. 3) and MTT dye reduction assay (Fig. 4) confirming that HL-60 is more prone to apoptosis than U937 cells. In addition to this observation HL-60 cells did not show the significant loss of cell viability at higher concentration of $\beta$-carotene (Fig. 2) confirming that cells did differentiate to myleiodic type and underwent apoptosis as clearly seen by DNA ladder assay. Moreover, $\beta$-carotene did not exhibit any cytotoxic effect towards the normal cells confirming that the effect is cellular specific. Findings from our studies suggest that low doses of $\beta$-carotene are dramatically effective in acute promyelocytic leukemia and show considerable promise.

The growth inhibitory effect of $\beta$-carotene in HL-60 was accompanied by an arrest in cell cycle. There are some indications that carotene are able to modify the cell cycle pattern. For example, lycopene (Amir et al., 1999) and $\alpha$ carotene (Murakoshi et al., 1989) were able to block $\mathrm{G}_{0} / \mathrm{G}_{1}$ phase of the cell cycle. However, $\beta$-carotene $(>70 \mu \mathrm{M})$ prevents the G2/M phase of cell cycle in oral cancer cell line SCS25 (Schwartz, 1993). Our experiments regarding DNA fragmentation (Fig. 6a) leads to the view that $\beta$-carotene must have blocked the downstream caspases to degrade the DNA by DNAses. However, we have not studied any mechanism of pathway in this experiment. In order to identify the nature of mechanism which governs the rate of apoptosis in $\beta$-carotene treated cells, we evaluated the intracellular ROS generation by DCFH-DA shift assay. Clear differences in ROS production was noticed between treated and control cells (Fig. 8). This result is similar to that found in colon cancer cells (Bortuzzo et al., 1996) and leukemia cells (Palozza et al., 2002). Cytochrome $\mathrm{C}$ is an electron carrier in oxidative phosphorylation mechanism in mitochondria (Matsuno-Yagi and Hatefi, 1996). It has been recently revealed that cytochrome $\mathrm{C}$ is the potent catalyst of DCF oxidation (Burkitt and Wardman, 2001). In 
the present investigation, untreated group showed an increase in fluorescence in both cell lines (Fig. 8). This is an indication that cytochrome $\mathrm{C}$ is released into cytoplasm. However, in cells treated with up to $20 \mu \mathrm{M} \beta$-carotene, the degree of fluorescence is decreased, confirming ROS scavenging. Alternatively, in higher concentrations, the rate of ROS production was increased.

Reactive oxygen species (ROS), such as superoxide anion radical $\left(\mathrm{O}_{2}^{-\bullet}\right)$, hydroxyl radicals $\left(\mathrm{OH}^{-}\right)$and peroxyl radicals $\left(\mathrm{ROO}^{-}\right)$, are produced as a part of normal metabolic processes. It has been reported that an elevation in ROS production does induce accumulation of inhibitors of cyclin dependent kinases, mainly p $21^{\mathrm{WAF}-1}$ (Esposito et al., 2000). It is possible that $\beta$ carotene cleaves into retinoic acid and acts as pro-oxidant in cancer cells like small lung cancer cells (Prakash et al., 1999) and colon adenocarcinoma cells (Quick and Ong, 1990). Results accumulated here show a decrease in cell viability and cell numbers even though oxidation state of the cell increased at higher concentrations. This particular observation needs to be tested since we have not done any experiments on the relationship between apoptosis and pro-oxidation nature of $\beta$ carotene.

The significance of the present study lies in the observation that $\beta$-carotene induces apoptosis through cell cycle arrest by the mechanism of ROS scavenging system. However, in vivo study warrants further confirmation that $\beta$-carotene acts as apoptosis agent in cancer cells particularly leukemia cells but not normal cells.

\section{References}

Aggarwal, B. B. and Shishodia, S. (2006) Molecular targets of dietary agents for prevention and therapy of cancer. Biochem. Pharmacol. 71, 1397-1421.

Altucci, L., Rossin, A., Raffelsberger, W., Reitmair, A., Chomienne, C. and Gronemeyer, H. (2001) Retinoic acid-induced apoptosis in leukemia cells is mediated by paracrine action of tumor-selective death ligand TRAIL. Nat. Med. 7, 680-686.

Amir, H., Karas, M., Giat, J., Danilenko, M., Levy, R., Yermiahu, T., Levy, J. and Sharoni, Y. (1999) Lycopene and 1,25dihydroxyvitamin D3 cooperate in the inhibition of cell cycle progression and induction of differentiation in HL-60 leukemic cells. Nutr. Cancer 33, 105-112.

Bortuzzo, C., Hanif, R., Kashfi, K., Staiano-Coico, L., Shiff, S. J. and Rigas, B. (1996) The effect of leukotrienes B and selected HETEs on the proliferation of colon cancer cells. Biochim. Biophys. Acta 1300, 240-246.

Burkitt, M. J. and Wardman, P. (2001) Cytochrome C is a potent catalyst of dichlorofluorescin oxidation: implications for the role of reactive oxygen species in apoptosis. Biochem. Biophys. Res. Commun. 282, 329-333.

Collins, S. J. (2002) The role of retinoids and retinoic acid receptors in normal hematopoiesis. Leukemia 16, 1896-1905.

Covacci, V., Bruzzese, N., Sgambato, A., Di Francesco, A., Russo, M. A., Wolf, F. I. and Cittadini, A. (1998) Magnesium restriction induces granulocytic differentiation and expression of p27Kip1 in human leukemic HL-60 cells. J. Cell. Biochem. 70, 313-322.

Esposito, F., Russo, L., Russo, T. and Cimino, F. (2000) Retinoblastoma protein dephosphorylation is an early event of cellular response to prooxidant conditions. FEBS Lett. 470, 211215.

Genkinger, J. M., Hunter, D. J., Spiegelman, D., Anderson, K. E., Arslan, A., Beeson, W. L., Buring, J. E., Fraser, G. E., Freudenheim, J. L., Goldbohm, R. A., Hankinson, S. E., Jacobs, D. R., Jr., Koushik, A., Lacey, J. V., Jr., Larsson, S. C., Leitzmann, M., McCullough, M. L., Miller, A. B., Rodriguez, C., Rohan, T. E., Schouten, L. J., Shore, R., Smit, E., Wolk, A., Zhang, S. M. and Smith-Warner, S. A. (2006) Dairy products and ovarian cancer: a pooled analysis of 12 cohort studies. Cancer Epidemiol. Biomarkers Prev. 15, 364-372.

Herrmann, M., Lorenz, H.-M., Voll, R., Griinke, M., Woith, W. and Kalden, J. R. (1994) A rapid and simple method for the isolation of apoptotic DNA fragments 10.1093/nar/22.24.5506. Nucleic Acids Res. 22, 5506-5507.

Jarrett, S. G., Cuenco, J. and Boulton, M. (2006) Dietary antioxidants provide differential subcellular protection in epithelial cells. Redox Rep. 11, 144-152.

Jing, Y., Ohizumi, H., Kawazoe, N., Hashimoto, S., Masuda, Y., Nakajo, S., Yoshida, T., Kuroiwa, Y. and Nakaya, K. (1994) Selective inhibitory effect of bufalin on growth of human tumor cells in vitro: association with the induction of apoptosis in leukemia HL-60 cells. Jpn. J. Cancer Res. 85, 645-651.

Konishi, I., Hosokawa, M., Sashima, T., Kobayashi, H., Miyashita, K. (2006) Halocynthiaxanthin and fucoxanthinol isolated from Halocynthia roretzi induce apoptosis in human leukemia, breast and colon cancer cells. Comp. Biochem. Physiol. C Toxicol. Pharmacol. 142, 53-59.

Koushik, A., Hunter, D. J., Spiegelman, D., Anderson, K. E., Buring, J. E., Freudenheim, J. L., Goldbohm, R. A., Hankinson, S. E., Larsson, S. C., Leitzmann, M., Marshall, J. R., McCullough, M. L., Miller, A. B., Rodriguez, C., Rohan, T. E., Ross, J. A., Schatzkin, A., Schouten, L. J., Willett, W. C., Wolk, A., Zhang, S. M. and Smith-Warner, S. A. (2006) Intake of the major carotenoids and the risk of epithelial ovarian cancer in a pooled analysis of 10 cohort studies. Int. J. Cancer 119, 2148-2154.

Maillard, V., Hoinard, C., Arab, K., Jourdan, M. L., Bougnoux, P. and Chajes, V. (2006) Dietary $\beta$-carotene inhibits mammary carcinogenesis in rats depending on dietary alpha-linolenic acid content. Br. J. Nutr. 96, 18-21.

Matsuno-Yagi, A. and Hatefi, Y. (1996) Ubiquinol-cytochrome c oxidoreductase. The redox reactions of the bis-heme cytochrome $b$ in ubiquinone-sufficient and ubiquinone-deficient systems. $J$. Biol. Chem. 271, 6164-6171.

McCarty, M. F. and Block, K. I. (2006) Toward a core nutraceutical program for cancer management. Integr. Cancer Ther. 5, 150-171.

Mosmann, T. (1983) Rapid colorimetric assay for cellular growth and survival: application to proliferation and cytotoxicity assays. J. Immunol. Methods 65, 55-63.

Murakoshi, M., Takayasu, J., Kimura, O., Kohmura, E., Nishino, H., Iwashima, A., Okuz $\mu$ Mi, J., Sakai, T., Sugimoto, T., Imanishi, J. and et al. (1989) Inhibitory effects of alpha-carotene on proliferation of the human neuroblastoma cell line GOTO. $J$. Natl. Cancer Inst. 81, 1649-1652.

Neuhouser, M. L., Patterson, R. E., Thornquist, M. D., Omenn, G. S., King, I. B. and Goodman, G. E. (2003) Fruits and vegetables are associated with lower lung cancer risk only in the placebo arm of 
the $\beta$-carotene and retinol efficacy trial (CARET). Cancer Epidemiol. Biomarkers Prev. 12, 350-358.

Noguchi, P. D. and Browne, W. C. (1978) The use of chicken erythrocyte nuclei as a biological standard for flow microfluorometry. J. Histochem. Cytochem. 26, 761-763.

Phalen, T. J., Weirather, K., Deming, P. B., Anathy, V., Howe, A. K., Van der Vliet, A., Jonsson, T. J., Poole, L. B., Heintz, N. H. (2006) Oxidation state governs structural transitions in peroxiredoxin II that correlate with cell cycle arrest and recovery. J. cell boil. 175, 779-89.

Palozza, P., Serini, S., Torsello, A., Boninsegna, A., Covacci, V., Maggiano, N., Ranelletti, F. O., Wolf, F. I. and Calviello, G. (2002) Regulation of cell cycle progression and apoptosis by $\beta$ carotene in undifferentiated and differentiated HL-60 leukemia cells: possible involvement of a redox mechanism. Int. J. Cancer
97, 593-600.

Paolini, M., Abdel-Rahman, S. Z., Sapone, A., Pedulli, G. F., Perocco, P., Cantelli-Forti, G. and Legator, M. S. (2003) $\beta$ carotene: a cancer chemopreventive agent or a co-carcinogen? Mutat. Res. 543, 195-200.

Prakash, P., Jackson, C. L. and Gerber, L. E. (1999) Sub-cellular accumulation of $\beta$-carotene and retinoids in growth-inhibited NCI-H69 small cell lung cancer cells. Nutr. Cancer 34, 76-82.

Quick, T. C. and Ong, D. E. (1990) Vitamin A metabolism in the human intestinal Caco-2 cell line. Biochemistry 29, 11116-11123.

Schreinemachers, D. M. and Everson, R. B. (1994) Aspirin use and lung, colon, and breast cancer incidence in a prospective study. Epidemiology 5, 138-146.

Schwartz, J. L. (1993) In vitro biological methods for determination of carotenoid activity. Methods Enzymol. 214, 226-256. 